\title{
Overexpression of Apg-2 increases cell proliferation and protects from oxidative damage in BaF3-BCR/ABL cells
}

\author{
CHUNLI LI $^{1 *}$, DINGBIN LIU ${ }^{1 *}$, YING YUAN ${ }^{2}$, SHIFENG HUANG $^{1}$, MENG SHI $^{1}$, KUN TAO $^{1}$ and WENLI FENG $^{1}$ \\ ${ }^{1}$ Department of Clinical Hematology, Key Laboratory of Laboratory Medical Diagnostics Designated \\ by the Ministry of Education; ${ }^{2}$ Department of General Surgery, The First Affiliated Hospital, \\ Chongqing Medical University, Chongqing 400016, P.R. China
}

Received November 2, 2009; Accepted January 4, 2010

DOI: 10.3892/ijo_00000568

\begin{abstract}
Apg-2, a mammalian heat-shock protein belonging to the heat-shock protein 110 (Hsp110) family, was previously found to be overexpressed in $\mathrm{BaF} 3-\mathrm{BCR} / \mathrm{ABL}$ cells that were treated with hydrogen peroxide $\left(\mathrm{H}_{2} \mathrm{O}_{2}\right)$ through our comparative proteomics study. The expression of Apg-2 in chronic myelogenous leukemia (CML) cells and its role have not been investigated, forming the basis for this study. BaF3MIGR1 and BaF3-BCR/ABL cell lines stably overexpressing Apg-2 were established and exposed to $50 \mu \mathrm{M} \mathrm{H}_{2} \mathrm{O}_{2}$ for $10 \mathrm{~min}$. Western blot analysis of Apg-2 expression confirmed that $\mathrm{H}_{2} \mathrm{O}_{2}$ treatment significantly up-regulated Apg-2 expression. Apg-2 overexpression elevated BaF3-BCR/ABL cell proportions in $\mathrm{S}$ and $\mathrm{G}_{2} / \mathrm{M}$ phase, increased cell proliferation and colony formation in vitro. Moreover, BaF3MIGR1 and BaF3-BCR/ABL cells were exposed to $50 \mu \mathrm{M}$ $\mathrm{H}_{2} \mathrm{O}_{2}$ in the absence or presence of Apg-2 overexpression and induction of $\mathrm{H}_{2} \mathrm{AX}$ phosphorylation, the reporters of DNA damage were assessed by Western blot and immunofluorescence. Results showed that exposure to $\mathrm{H}_{2} \mathrm{O}_{2}$ induced $\mathrm{H}_{2} \mathrm{AX}$ phosphorylation in BaF3-MIGR1 cells, but no increase was observed in BaF3-BCR/ABL cells. Together, the data indicate that Apg-2 is overexpressed and overexpression of Apg-2 in BaF3-BCR/ABL cells increases cell proliferation and protects cells from oxidative damage, which may play an important role in CML carcinogenesis and progression.
\end{abstract}

\footnotetext{
Correspondence to: Professor Wenli Feng, Department of Clinical Hematology, Key Laboratory of Laboratory Medical Diagnostics Designated by the Ministry of Education, Chongqing Medical University, Chongqing 400016, P.R. China

E-mail: fengwlcqmu@sina.com

*Contributed equally
}

Abbreviations: CML, chronic myelogenous leukemia; $\mathrm{H}_{2} \mathrm{O}_{2}$, hydrogen peroxide; Hsp, heat shock protein

Key words: Apg-2, hydrogen peroxide, overexpression, cell proliferation, $\mathrm{H}_{2} \mathrm{AX}$

\section{Introduction}

$\mathrm{BCR} / \mathrm{ABL}$ protein with deregulated tyrosine kinase activity is encoded by the BCR/ABL gene, which is a result of the $t(9 ; 22)(q 34 ; q 11)$ chromosomal translocation. This fusion oncoprotein plays a central role in the pathogenesis of chronic myeloid leukemia (CML). Recently, imatinib mesylate (IM), which is an inhibitor of the BCR-ABL tyrosine kinase, has shown promise in treating CML patients (1). However, early relapses and IM-resistance have emerged as significant clinical problems in some IM-treated CML patients (2). Thus, it is critical to identify other therapeutics to prevent relapses and acquisition of resistance.

Heat-shock proteins (HSPs), also called stress proteins, are highly conserved proteins whose expressions are induced by various stresses (3). Recent studies have shown that overexpression of Hsp27, Hsp70, Hsp60 or Hsp90 inhibited apoptosis and prevented caspase activation in many different cellular models upon a variety of cellular stresses, including accumulation of misfolded proteins, reactive oxygen species (ROS) or DNA damage (3-6). Wang et al (7) also reported that Hsp110, Hsp70 and Hsp25 formed a large complex and directly interacted with one another in cell proliferation, cell cycle and protection from environmental stress. In addition, it is well known that Hsp70, one of the ATP-dependent molecular chaperones (8), is overexpressed in a multitude of cancers and is believed to play a role in tumorigenesis (9) DNA repair (10-12) and imatinib resistance in CML (13).

Apg (ATP and peptide-binding protein in germ cells)-2, a member of Hsp110 subfamily belonging to the Hsp70 family (14), was recently cloned from a mouse testis cDNA library using Apg-1 cDNA as a probe (15). Interestingly, Apg-2 protein shows a chaperone-like activity similar to Hsp110 and is overexpressed in hepatocellular carcinomas (16) as well as in pancreatic cancer (17), indicating that Apg-2 may be critical to tumor progression. In our previous comparative proteomics study, we found that Apg-2 was overexpressed in $\mathrm{BaF} 3-\mathrm{BCR} / \mathrm{ABL}$ cells that were treated with hydrogen peroxide $\left(\mathrm{H}_{2} \mathrm{O}_{2}\right)$ comparing to $\mathrm{BaF} 3-\mathrm{MIGR} 1$ cells (unpublished data). However, its underlying mechanisms are still unclarified.

Based on these studies, we hypothesized that overexpression of Apg-2 in BaF3-BCR/ABL cells that were treated with 
$\mathrm{H}_{2} \mathrm{O}_{2}$ might contribute to cell proliferation, cell cycle and protection from environmental stress. In the present study, BaF3-MIGR1 and BaF3-BCR/ABL cell lines overexpressing Apg-2 were established and treated with $\mathrm{H}_{2} \mathrm{O}_{2}$. We demonstrated for the first time that Apg-2 was overexpressed in BaF3-BCR/ABL cells when treated with $\mathrm{H}_{2} \mathrm{O}_{2}$, which not only increased cell proliferation and colony formation, but also effectively protected cells from $\mathrm{H}_{2} \mathrm{O}_{2}$-induced injury.

\section{Materials and methods}

Cell culture and treatment. Murine pro-B cells BaF3 carrying MIGR1 vector (named BaF3-MIGR1) and p210 $10^{\mathrm{BCR} / \mathrm{ABL}}$ (named BaF3-BCR/ABL) were established by our group. The cells were grown in RPMI-1640 (Gibco-BRL, Invitrogen, UK) supplemented with $10 \%$ fetal bovine serum (FBS; Gibco-BRL, Invitrogen), $100 \mathrm{U} / \mathrm{ml}$ penicillin, $100 \mu \mathrm{g} / \mathrm{ml}$ streptomycin, and $1 \mathrm{ng} / \mathrm{ml}$ murine interleukin 3 (IL-3) but $\mathrm{BaF} 3-\mathrm{BCR} / \mathrm{ABL}$ cells without IL-3 in a $5 \% \mathrm{CO}_{2}$ humidified atmosphere at $37^{\circ} \mathrm{C}$. Cells $\left(\sim 2 \times 10^{6}\right)$ were harvested and treated with $50 \mu \mathrm{M} \mathrm{H}_{2} \mathrm{O}_{2}$ at $4^{\circ} \mathrm{C}$ for $10 \mathrm{~min}$.

Plasmid preparations and transfections. pCMV-Apg-2 containing full-length of murine Apg-2 cDNA was kindly provided by Professor Tongchuan He (Chicago Medical Center, USA). Full-length Apg-2 cDNA (GenBank accession number NM_008300) was digested with BglII and SacII (New England BioLabs, Ipswich, MA, USA) and cloned to eukaryotic expression plasmid pIERS2-EGFP (preserved by our laboratory). Restriction sites were introduced by the forward primer (5'-GAAGATCTATGTCGGTGGTGGG CATAGACCTGGG-3') and the reverse primer (5'-TCC CCGCGGTCAATCAATGTCCATCTCAGGAAGCTT-3'). Sequence fidelity was confirmed by DNA sequencing. Cells $\left(\sim 5 \times 10^{6}\right)$ plus $20 \mu \mathrm{g}$ of plasmid DNAs were mixed in a Bio-Rad gene Pulser Cuvette and incubated at $4^{\circ} \mathrm{C}$ for $10 \mathrm{~min}$. Following one pulse electroporation $(270 \mathrm{~V}, 960 \mu \mathrm{F})$, cells were incubated at $4^{\circ} \mathrm{C}$ for $10 \mathrm{~min}$ and resuspended in RPMI-1640 plus $15 \%$ fetal bovine serum with $1 \mathrm{ng} / \mathrm{ml}$ murine interleukin 3 (IL-3). The transfected cells were first plated on 24-well dishes and selected in the presence of $800 \mu \mathrm{g} / \mathrm{ml}$ $\mathrm{G} 418$ at $37^{\circ} \mathrm{C}, 5 \% \mathrm{CO}_{2}$ for 10 days. Then, selected resistant clones were expanded in 10-cm culture dishes for additional analysis.

Western blot analysis. Cells were washed with ice-cold PBS three times and lysed with lysis buffer. Protein concentrations were measured by modified Bradford assay. Protein extracts $(\sim 50-80 \mu \mathrm{g})$ were separated by $8-12 \%$ SDS-PAGE and transferred to polyvinylidene difluoride (PVDF) membranes. After membranes were blocked, followed by an overnight incubation with anti-Apg-2 (Santa Cruz, CA) and phospho-specific (Ser-139) histone $\mathrm{H}_{2} \mathrm{AX}\left(\gamma-\mathrm{H}_{2} \mathrm{AX}\right)$ rabbit polyclonal antibody at $4{ }^{\circ} \mathrm{C}$ and then with the HRPconjugated secondary anti-rabbit antibody (St. Louis, MO) at room temperature for $60 \mathrm{~min}$. The immunoblots were revealed by autoradiography using enhanced chemiluminescence (ECL) detection kit (Millipore, Bedford, MA) and the band intensity was measured by densitometry using the
Quantity One software (Bio-Rad Laboratories, Inc. Hercules, CA). The protein levels were normalized with respect to $B$ actin protein level.

Cell cycle analysis. Cells were harvested and washed with ice-cold PBS and fixed with $70 \%$ ethanol overnight at $4{ }^{\circ} \mathrm{C}$. Propidium iodine $(10 \mu \mathrm{g} / \mathrm{ml})$ supplemented with RNase A $\left(200 \mu \mathrm{g} / \mathrm{ml}\right.$ ) was added to the cells for $30 \mathrm{~min}$ (at $37^{\circ} \mathrm{C}$ ) in the dark prior to FACS analysis (BD Biosciences, San Jose, CA). Percentages of $G_{0} / G_{1}, S$ and $G_{2} / M$ phase cells were determined using Modfit LT software (Verity Software House, Topsham, ME).

Cell proliferation assay. Cells $\left(\sim 2 \times 10^{3}\right)$ were cultured in 96-well microplates (Falcon Plastic, CA, USA) using $100 \mu 1$ optimal medium. At each time point (days 1, 3, 5, 7), $10 \mu 1$ of SunBio ${ }^{\mathrm{TM}}$ Am-Blue (Shanghai Sun-Bio, China) was added to each well, and incubation at $37^{\circ} \mathrm{C}$ and $5 \% \mathrm{CO}_{2}$ was continued for $6 \mathrm{~h}$ before measurement in triplicate for each time point. The relative fluorescent units (RFU) of living cells were detected by fluorescence microplate reader (CytoFluor, AB, USA) at different time points. RFU are directly proportional to number of living cells.

Methylcellulose colony formation assay. Cells were cultured in the methylcellulose media consisting of RPMI-1640 containing 0.9\% methylcellulose (Aqua Solutions, Deer Park, TX), $20 \%$ fetal bovine serum, $100 \mathrm{U} / \mathrm{ml}$ penicillin, $100 \mu \mathrm{g} / \mathrm{ml}$ streptomycin at the appropriate concentration and were plated at a density of 2000/ml in $1 \mathrm{ml}$ volume in humidified 24-well plates. After 10 days of culture, the number of cell clones with $>50$ cells was counted under microscope in each well (clone formation rate $=$ number of clones in each dish/2000). Three reduplicate wells were used from each clone.

Immunofluorescence. Cells were washed with ice-cold PBS three times. Cytospin slides of $2 \times 10^{5}$ each group cells were prepared according to standard procedures and fixed in $100 \%$ prechilled methanol at $-20^{\circ} \mathrm{C}$ for $30 \mathrm{~min}$. Following three washes with $\mathrm{PBS}(\mathrm{pH} 7.2)$, slides were permeabilized with $0.3 \%$ Triton $\mathrm{X}-100 / \mathrm{PBS}$ for $15 \mathrm{~min}$ at $37^{\circ} \mathrm{C}$, blocked in $10 \%$ normal goat serum for $3 \mathrm{~h}$ at room temperature and incubated with indicated antibodies at $4{ }^{\circ} \mathrm{C}$ overnight followed by three washes with PBS (pH 7.2) containing 0.5\% Triton-X 100 (Sigma, St. Louis, MO). The cells were further incubated with goat anti-rabbit PE-IgG, washed, and DNA was counterstained with DAPI for 3 min. After three washes with PBS, the cells were treated with a fluorescent mounting medium (Dako), and visualized by confocal microscopy (LEICALasertech GmbH, Heidelberg, Germany). Fluorescence images were acquired by means of a PL-APO x 100 objective. In order to confirm the cellular localization in the 3-D images, 4-sectioned images were overlapped into a single image at the same phase.

Statistical analysis. Data were expressed as means \pm SE. All the data were analyzed using the SPSS statistical package 13.0. Mean values were compared by unpaired t-test. $\mathrm{P}<0.05$ were considered statistically significant. 

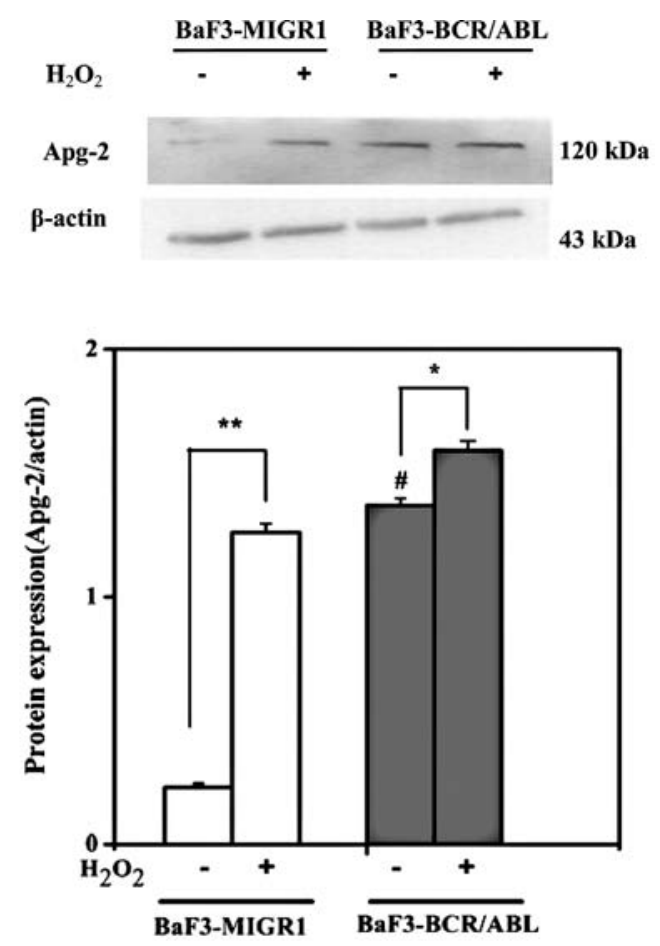

Figure 1. Western blot analysis of Apg-2 expression in cells exposed to $\mathrm{H}_{2} \mathrm{O}_{2}$. BaF3-MIGR1 and BaF3-BCR/ABL cells were exposed to $50 \mu \mathrm{M}$ $\mathrm{H}_{2} \mathrm{O}_{2}$ at $4^{\circ} \mathrm{C}$ for $10 \mathrm{~min}$, then the cells were collected for Western blot analysis. Data are representative of three independent experiments. ${ }^{*} \mathrm{p}<0.05$, ${ }^{* *} \mathrm{p}<0.01$ vs untreated cells; ${ }^{\#} \mathrm{p}<0.05 \mathrm{BaF} 3-\mathrm{BCR} / \mathrm{ABL}$ cells vs BaF3-MIGR1 cells.

\section{Results}

$\mathrm{H}_{2} \mathrm{O}_{2}$ treatment accumulated Apg-2 expression in BaF3BCR/ABL cells. $\mathrm{H}_{2} \mathrm{O}_{2}(50 \mu \mathrm{M})$ was applied to BaF3-MIGR1 and $\mathrm{BaF} 3-\mathrm{BCR} / \mathrm{ABL}$ cells for $10 \mathrm{~min}$, and Apg-2 expression was assessed by Western blot. As shown in Fig. 1, Apg-2 protein expression was up-regulated after exposure to $\mathrm{H}_{2} \mathrm{O}_{2}$, and $\mathrm{BaF} 3-\mathrm{BCR} / \mathrm{ABL}$ cells displayed much higher level than BaF3-MIGR1 cells, which was lined with our previous comparative proteomics study (unpublished data). To investigate the potential role of Apg-2 in BCR/ABL-positive cells, both BaF3-BCR/ABL cell lines and the peer BaF3MIGR1 cell lines for control stably overexpressing Apg-2 were constructed. Western blot analysis identified that the
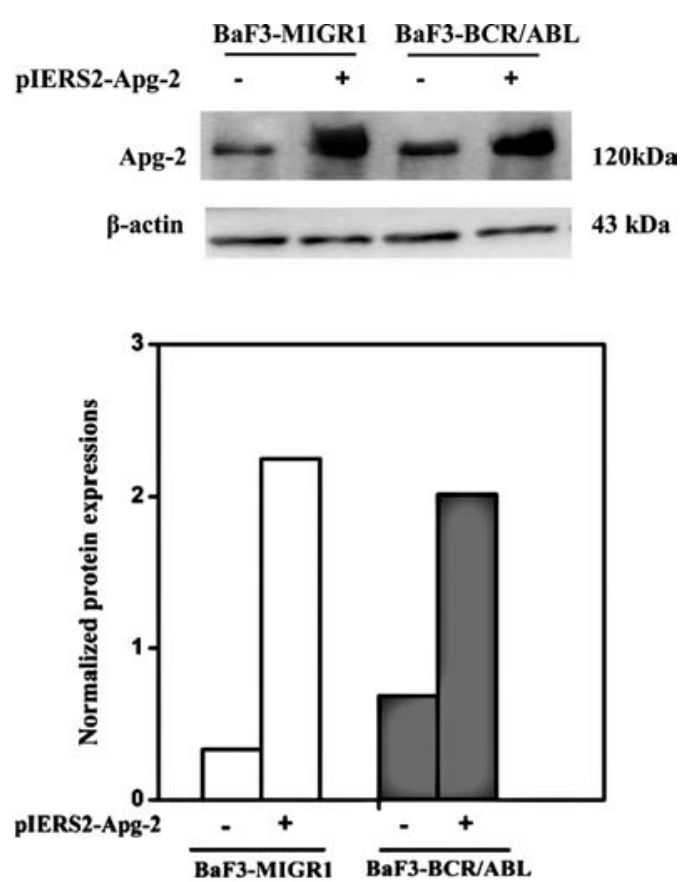

Figure 2. Western blot analysis of Apg-2 expression in cells transfected with pIERS2-Apg-2 gene. Apg-2 protein expression was analyzed by Western blot as described in the text. B-actin is shown as internal standard for the amount of protein applied in the samples. The band intensity was measured by densitometry using the Quantity One software.

expression levels of the Apg-2 protein in the pIERS2-Apg-2transfected cells were approximately three-fold higher than that in the controls (Fig. 2).

BaF3-BCR/ABL cells with Apg-2 overexpression had higher proportions of $S$ and $G_{2} / M$ phase. To monitor the effect of Apg-2 overexpression on the cell cycle, the DNA content of transfected cells was analyzed by FACS. The results showed that the proportion of BaF3-MIGR1-Apg-2 cells in $\mathrm{G}_{0} / \mathrm{G}_{1}$ phase was increased to $53.39 \pm 0.45 \%(\mathrm{P}<0.05)$, while the proportion of BaF3-MIGR1-Apg-2 cells in $\mathrm{S}$ phase was reduced to $41.29 \pm 1.08 \%(\mathrm{P}<0.05)$. On the other hand, $\mathrm{BaF} 3$ BCR/ABL-Apg-2 cells showed lower proportion in $G_{0} / G_{1}$ phase $(20.87 \pm 0.38)$ and higher proportion in $S$ phase and $\mathrm{G}_{2} / \mathrm{M}$ phase $(71.45 \pm 1.34 \%$ and $7.69 \pm 0.96 \%)$ compared with BaF3-BCR/ABL cells (Table I and Fig. 3). BaF3-BCR/ABL-

Table I. Cell cycle analysis by flow cytometry.

\begin{tabular}{llll}
\hline Group & $\mathrm{G}_{0} / \mathrm{G}_{1}(\%)$ & $\mathrm{S}(\%)$ & $\mathrm{G}_{2} / \mathrm{M}^{(\%)}$ \\
\hline BaF3-MIGR1 & $37.39 \pm 0.38$ & $60.04 \pm 0.70$ & $2.57 \pm 1.05$ \\
BaF3-MIGR1-Apg-2 & $53.39 \pm 0.45^{\mathrm{a}}$ & $41.29 \pm 1.08^{\mathrm{a}}$ & $5.32 \pm 1.53^{\mathrm{a}}$ \\
BaF3-BCR/ABL & $28.27 \pm 0.25^{\mathrm{b}}$ & $66.72 \pm 0.73^{\mathrm{b}}$ & $5.01 \pm 0.99^{\mathrm{b}}$ \\
BaF3-BCR/ABL-Apg-2 & $20.87 \pm 0.38^{\mathrm{a}}$ & $71.45 \pm 1.34^{\mathrm{a}}$ & $7.69 \pm 0.96^{\mathrm{a}}$ \\
\hline
\end{tabular}

Cell cycle profiling by flow cytometric analysis of DNA content was performed on the overexpression cells and the control groups. Percentages of $\mathrm{G}_{0} / \mathrm{G}_{1}, \mathrm{~S}$ and $\mathrm{G}_{2} / \mathrm{M}$ phase cells were calculated with Modfit LT software. Results are the average of 3 experiments. Values are means $( \pm \mathrm{SE}) .{ }^{\mathrm{a}} \mathrm{P}<0.05$ vs untransfected cells; ${ }^{\mathrm{b}} \mathrm{P}<0.05$ vs BaF3-MIGR1 cells. 

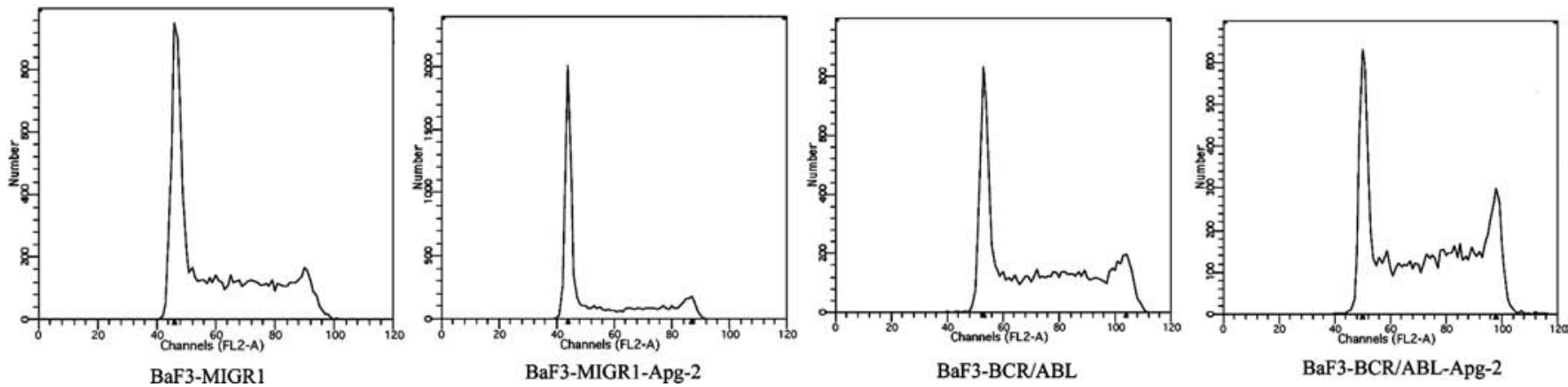

Figure 3. Cell cycle analyzed by FACS. Representative FACS images of BaF3-MIGR1, BaF3-MIGR1-Apg-2, BaF3-BCR/ABL and BaF3-BCR/ABL-Apg-2 cells were from three independent experiments.

A

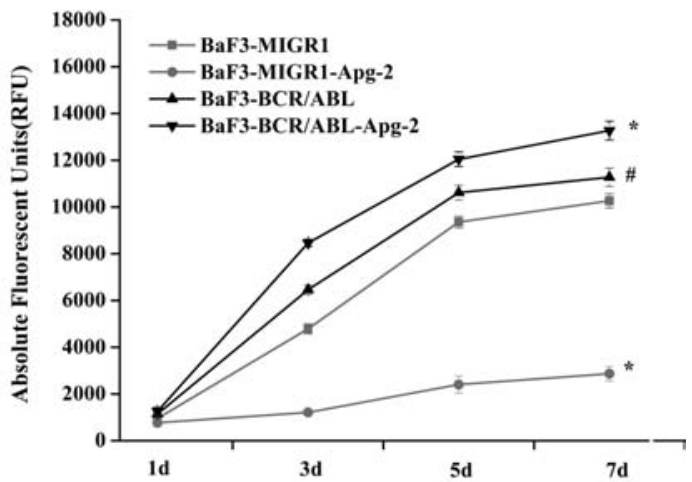

B

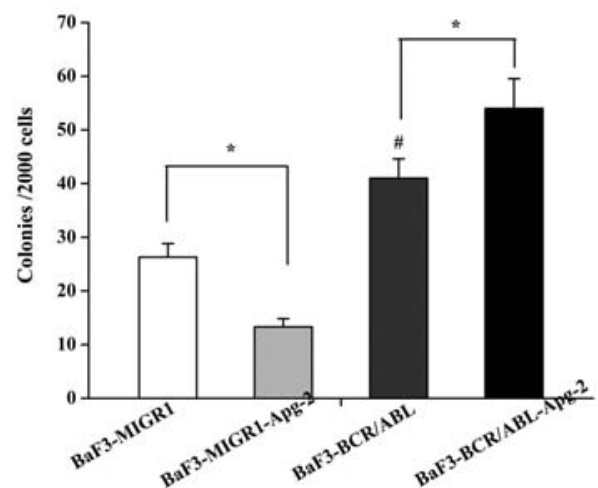

Figure 4. Cell proliferation and colony formation assays. (A) Effects of Apg-2 overexpression on cell proliferation. The details are described in the Materials and methods. Each point represents the mean \pm SE for 3 wells. Data shown are representative of 3 experiments. (B) Colony formation was examined as depicted in Materials and methods. The number of colony was counted at light microscope. Results represent means \pm SE of 3 separate experiments. ${ }^{*} \mathrm{p}<0.05$ vs untransfected cells, ${ }^{\#} \mathrm{p}<0.05 \mathrm{BaF} 3-\mathrm{BCR} / \mathrm{ABL}$ cells vs BaF3-MIGR1 cells. untransfected cells also displayed increased proportion in $S$ phase and $G_{2} / M$ phase.

Apg-2 overexpression increased cell proliferation and colony formation in BaF3-BCR/ABL cells. The growth properties of cells with Apg-2 overexpression in vitro were evaluated. In comparison to BaF3-MIGR1 cells, BaF3-BCR/ABL cells and BaF3-MIGR1-Apg-2 cells displayed increased and decreased cell viability, respectively. However, BaF3-BCR/ABL-Apg-2 cells showed higher cell viability, as tested by Am-Blue assay (Fig. 4A). BaF3-MIGR1-Apg-2 cells formed markedly less colonies than did in BaF3-MIGR1 cells, but Apg-2 overexpression revealed a $\sim 47 \%$ increase in colony formation in $\mathrm{BaF} 3-\mathrm{BCR} / \mathrm{ABL}$ cells as compared with $\mathrm{BaF} 3-\mathrm{BCR} /$ ABL cells (Fig. 4B).

Apg-2 overexpression protected $B a F 3-B C R / A B L$ cells from $\mathrm{H}_{2} \mathrm{O}_{2}$-induced oxidative damage. Earlier studies have shown that $\gamma-\mathrm{H}_{2} \mathrm{AX}$, a phosphorylated form of histone $\mathrm{H}_{2} \mathrm{AX}$ on Ser-139, is an early indicator of cellular DNA damage, particularly the damage that involves the formation of DNA double-strand breaks (DSBs) (18-20). Exposure to $\mathrm{H}_{2} \mathrm{O}_{2}$ resulted in induction of $\mathrm{H}_{2} \mathrm{AX}$ phosphorylation (Fig. 5), which was reinforced by Apg-2 overexpression in BaF3MIGR1 cells. But no response was elicited in BaF3-BCR/ ABL cells either by Apg-2 overexpression or $\mathrm{H}_{2} \mathrm{O}_{2}$ treatment. The constitutive phosphorylation of $\mathrm{H}_{2} \mathrm{AX}$ was also observed in untreated cells.

The induction of $\gamma-\mathrm{H}_{2} \mathrm{AX}$ manifested in form of IF foci (Fig. 6). The microphotographs shown in this figure demonstrate formation of a large number of $\gamma-\mathrm{H}_{2} \mathrm{AX}$ IF foci in

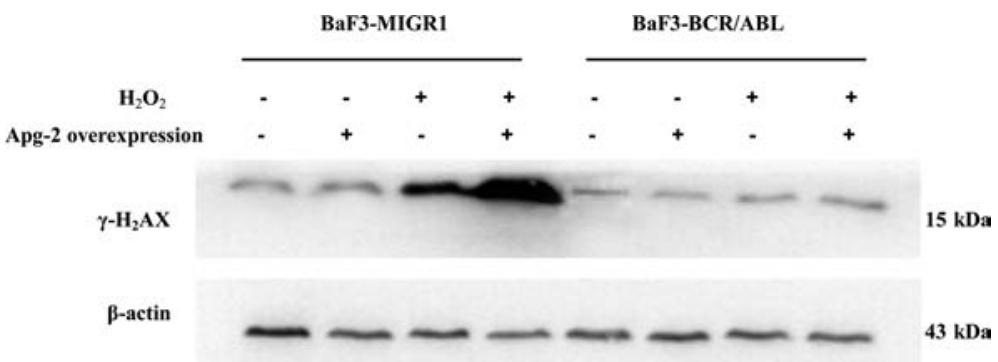

Figure 5. $\gamma-\mathrm{H}_{2} \mathrm{AX}$ expression in cells exposed to $\mathrm{H}_{2} \mathrm{O}_{2}$. Cells untreated or treated with $50 \mu \mathrm{M} \mathrm{H}_{2} \mathrm{O}_{2}$ were analyzed by Western blot for measurement of $\gamma-\mathrm{H}_{2} \mathrm{AX}$ expression. 
A BaF3-MIGR1

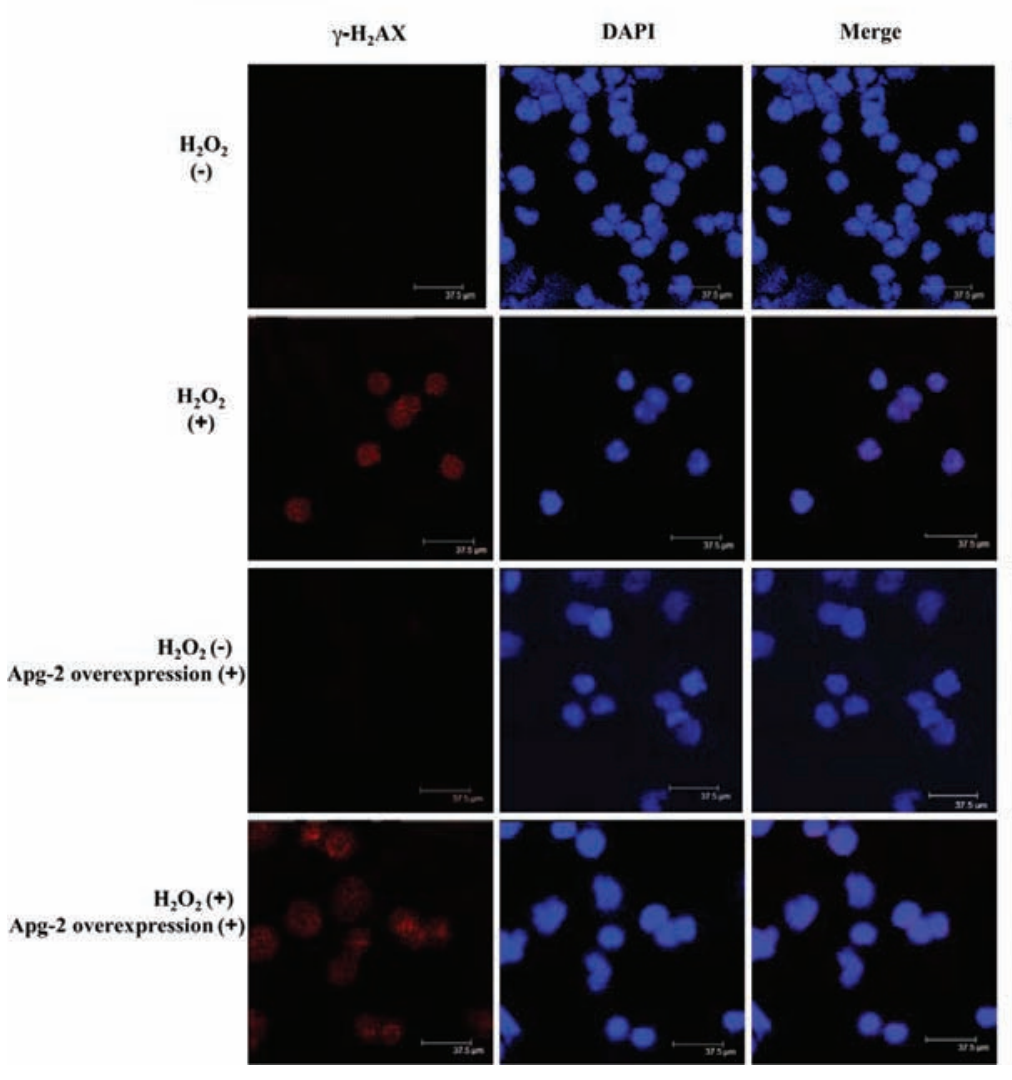

B BaF3-BCR/ABL

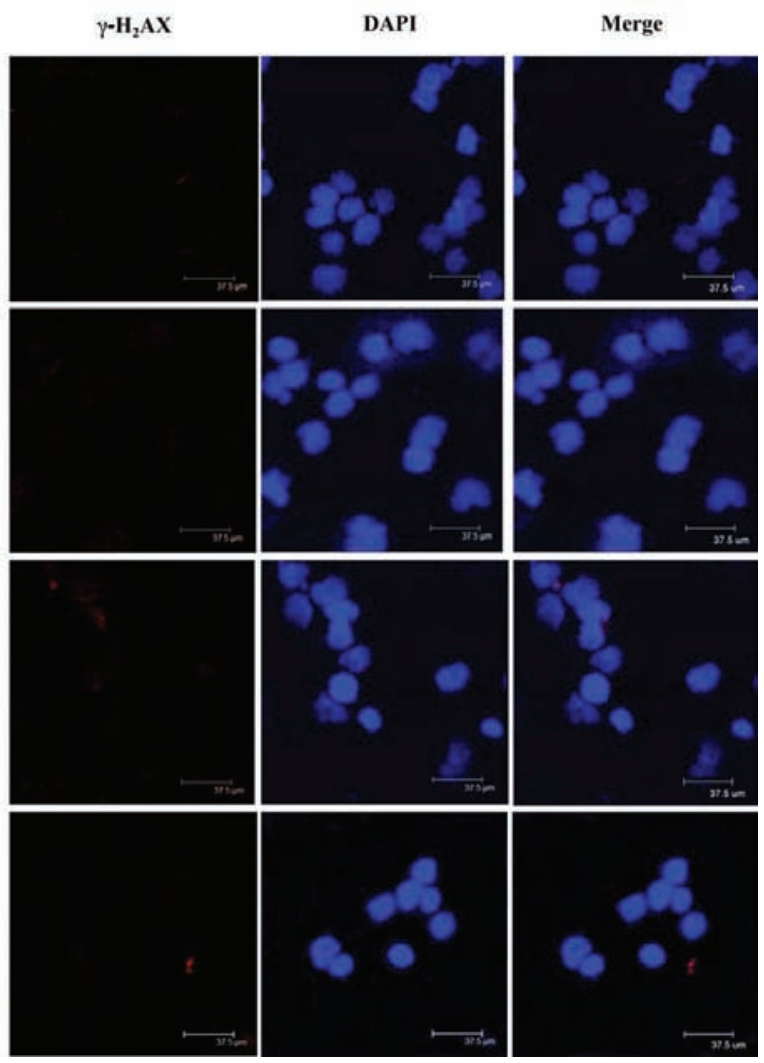

Figure 6. A and B, Confocal microscopic analysis of $\gamma-\mathrm{H}_{2} \mathrm{AX}$. Cells untreated or treated with $50 \mu \mathrm{M} \mathrm{H}_{2} \mathrm{O}_{2}$ were stained with anti- $\gamma-\mathrm{H}_{2} \mathrm{AX}$ antibody and PE-labeled goat anti-rabbit IgG (red), followed by DAPI counterstaining (blue).

BaF3-MIGR1 cells that were exposed to $\mathrm{H}_{2} \mathrm{O}_{2}$ or Apg-2 overexpression (Fig. 6A). However, there was almost total suppression of $\gamma-\mathrm{H}_{2} \mathrm{AX}$ IF foci formation in BaF3-BCR/ ABL cells that were exposed to $\mathrm{H}_{2} \mathrm{O}_{2}$ or Apg-2 overexpressed (Fig. 6B).

\section{Discussion}

This study demonstrated for the first time the following: a) $\mathrm{H}_{2} \mathrm{O}_{2}$ treatment leads to remarkable accumulation of Apg-2 expression in BaF3-MIGR1 and BaF3-BCR/ABL cells. b) Apg-2 is significantly up-regulated in BaF3-BCR/ABL cells as compared to that in BaF3-MIGR1 control cells. c) Apg-2 overexpression in $\mathrm{BaF} 3-\mathrm{BCR} / \mathrm{ABL}$ cells elevates cell proportions in $S$ and $G_{2} / M$ phase and increases cell proliferation. d) Overexpression of Apg-2 in BaF3-BCR/ ABL cells suppresses $\mathrm{H}_{2} \mathrm{AX}$ phosphorylation and $\gamma-\mathrm{H}_{2} \mathrm{AX}$ IF foci formation. These results clearly indicate the important role of Apg-2 in BaF3-BCR/ABL cells.

Apg-2, a member of the Hsp110 family, is overexpressed in carcinomas and is therefore thought to play a role during proliferation $(17,21-22)$. In the present study, we found that the expression of Apg-2 was increased when exposed to $\mathrm{H}_{2} \mathrm{O}_{2}$ and $\mathrm{BaF} 3-\mathrm{BCR} / \mathrm{ABL}$ cells also showed a higher level of Apg-2 as compared with BaF3-MIGR1 cells. Moreover, overexpression of Apg-2 conferred a proliferative advantage to $\mathrm{BaF} 3-\mathrm{BCR} / \mathrm{ABL}$ cells in vitro. In accord with our findings, a previous study has demonstrated that Apg-2 is overexpressed in hepatocellular carcinoma (16). Together, these findings suggested that Apg-2 is overexpressed when exposed to $\mathrm{H}_{2} \mathrm{O}_{2}$ in $\mathrm{BaF} 3-\mathrm{BCR} / \mathrm{ABL}$ cells, which promotes cell proliferation.

The present data illuminated that exposure of BaF3MIGR1 cells to $\mathrm{H}_{2} \mathrm{O}_{2}$ led to rapid induction of $\mathrm{H}_{2} \mathrm{AX}$ phosphorylation. This observation is compatible with the known mechanism of DNA damage by oxidants that initially leads to formation of DNA single-strand lesions, predominantly consisting of 8-oxo-dG, followed by conversion of some of these lesions into DSBs during DNA replication (23-25). Consistent with the induction of DSBs by $\mathrm{H}_{2} \mathrm{O}_{2}$ was also observation of $\gamma-\mathrm{H}_{2} \mathrm{AX}$ foci (Fig. 6). Therefore, the above evidence points out that in the cells treated with $\mathrm{H}_{2} \mathrm{O}_{2}$ the induction of $\gamma-\mathrm{H}_{2} \mathrm{AX}$ reports oxidative damage.

Oxidative damage induced by $\mathrm{H}_{2} \mathrm{O}_{2}$ as reflected by induction of $\gamma-\mathrm{H}_{2} \mathrm{AX}$ was distinctly reduced in BaF3-BCR/ ABL cells that were exposed to $\mathrm{H}_{2} \mathrm{O}_{2}$ in the presence of Apg-2 overexpression, which was similar to the level of $\gamma-\mathrm{H}_{2} \mathrm{AX}$ expression on the $\mathrm{H}_{2} \mathrm{O}_{2}$-untreated cells. These results provide evidence for the protective effect of Apg-2 on BaF3-BCR/ ABL cells stressed by $\mathrm{H}_{2} \mathrm{O}_{2}$. As mentioned, the constitutive phosphorylation of $\mathrm{H}_{2} \mathrm{AX}$ found in untreated cells reflects to a large extent the ongoing DNA damage induced by endogenous oxidants produced primarily in mitochondria during aerobic metabolism $(26,27)$. 
It is unclear why the cell proliferative advantage and protective effect on oxidative damage were only observed in BaF3-BCR/ABL cells with Apg-2 overexpression not in BaF3-MIGR1 cells. One of the mechanisms could be that Apg-2 had a chaperone-like activity (17), interacting with BCR/ABL. Previous study in radiated mice demonstrated that Apg-2 was involved in the induction of the radioadaptive response and played a role in the radiation-induced DNA damage (20). It is likely that Apg-2 interacting with BCR/ $\mathrm{ABL}$ promotes cell proliferation and protects cells from oxidative damage, which may be associated with $\mathrm{H}_{2} \mathrm{O}_{2}$ induced DNA repair.

Collectively, this study suggests that Apg-2 is overexpressed in BaF3-BCR/ABL cells and the cells that were exposed to $\mathrm{H}_{2} \mathrm{O}_{2}$. Overexpression of Apg-2 promotes cell proliferation and protects against oxidative damage in $\mathrm{BaF} 3$ BCR/ABL cells. Studies for precise understandings of the underlying mechanisms are under way. It may be possible to clarify carcinogenesis and progression of CML and develop novel strategies for CML treatment.

\section{Acknowledgments}

We thank Professor Tong-chuan He at Chicago Medical Center in America for his generous supply of the pCMVApg-2 plasmid, as well as his kind help in technical expertise and writing instructions. This work was supported by a grant from the Ph.D. Programs Foundation of Ministry of Education of China (No. 2005631007) to Wen-li Feng.

\section{References}

1. Kantarjian H, Sawyers C, Hochhaus A, et al: Hematologic and cytogenetic responses to imatinib mesylate in chronic myelogenous leukemia. N Engl J Med 346: 645-652, 2002.

2. O'Hare T, Corbin AS and Druker BJ: Targeted CML therapy: controlling drug resistance, seeking cure. Curr Opin Genet Dev 16: 92-99, 2006.

3. Garrido C, Brunet M, Didelot C, Zermati Y, Schmitt E and Kroemer G: Heat shock proteins 27 and 70: antiapoptotic proteins with tumorigenic properties. Cell Cycle 5: 2592-2601, 2006.

4. Garrido C, Bruey JM, Fromentin A, Hammann A, Arrigo AP and Solary E: HSP27 inhibits cytochrome c-dependent activation of procaspase-9. FASEB J 13: 2061-2070, 1999.

5. Mosser DD, Caron AW, Bourget L, Meriin AB, Sherman MY, Morimoto RI and Massie B: The chaperone function of hsp70 is required for protection against stress-induced apoptosis. Mol Cell Biol 20: 7146-7159, 2000.

6. Mosser DD and Morimoto RI: Molecular chaperones and the stress of oncogenesis. Oncogene 23: 2907-2918, 2004.

7. Wang XY, Chen X, Oh HJ, Repasky E, Kazim L and Subjeck J: Characterization of native interaction of hsp110 with hsp25 and hsc70. FEBS Lett 465: 98-102, 2000.
8. Wickner S, Maurizi MR and Gottesman S: Posttranslational quality control: folding, refolding, and degrading proteins. Science 286: 1888-1893, 1999.

9. Jäättelä M: Multiple cell death pathways as regulators of tumour initiation and progression. Oncogene 23: 2746-2756, 2004.

10. Burkart V, Liu H, Bellmann K, et al: Natural resistance of human beta cells toward nitric oxide is mediated by heat shock protein 70. J Biol Chem 275: 19521-19528, 2000.

11. Calini V, Urani C and Camatini M: Overexpression of HSP 70 is induced by ionizing radiation in $\mathrm{C} 3 \mathrm{H} 10 \mathrm{~T} 1 / 2$ cells and protects from DNA damage. Toxicol In Vitro 17: 561-566, 2003.

12. Gao YJ, Xiao CF, Chen S, Wang RB, He HZ, Tanguay RM and Wu TC: In vitro study on role of Hsp70 expression in DNA damage of human embryonic lung cells exposed to benzo[a]pyrene. Biomed Environ Sci 17: 144-152, 2004.

13. Pocaly M, Lagarde V, Etienne G, et al: Overexpression of the heat-shock protein 70 is associated to imatinib resistance in chronic myeloid Leukemia. Leukemia 21: 93-101, 2007.

14. Lee Yoon D, Easton D, Murawski M, Burd R and Subjeck JR: Identification of a major subfamily of large hsp70-like proteins through the cloning of the mammalian $110-\mathrm{kDa}$ heat shock protein. J Biol Chem 270: 15725-15733, 1995.

15. Kaneko Y, Kimura T, Kishishita M, Noda Y and Fujita J: Cloning of apg-2 encoding a novel member of the heat shock protein 110 family. Gene 189: 19-24, 1997.

16. Gotoh K, Nonoguchi K, Higashitsuji H, et al: Apg-2 has a chaperone-like activity similar to Hsp110 and is overexpressed in hepatocellular carcinomas. FEBS Lett 560: 19-24, 2004.

17. Nakatsura T, Senju S, Yamada K, Jotsuka T, Ogawa M and Nishimura Y: Gene cloning of immunogenic antigens overexpressed in pancreatic cancer. Biochem Biophys Res Commun 281: 936-944, 2001.

18. Kang CM, Park KP, Cho CK, Seo JS, Park WY, Lee SJ and Lee YS: Hspa4 (HSP70) is involved in the radioadaptive response: results from mouse splenocytes. Radiat Res 157: 650655, 2002.

19. Sedelnikova OA, Rogakou EP, Panyutin IG and Bonner WM: Quantitative detection of (125) IdU-induced DNA double-strand breaks with gmama- $\mathrm{H}_{2} \mathrm{AX}$ antibody. Radiat Res 158: 486-492, 2000.

20. Downs JA and Côté J: Dynamics of chromatin during the repair of DNA double-strand breaks. Cell Cycle 4: 1373-1376, 2005.

21. Downey M and Durocher D: $\gamma-\mathrm{H}_{2} \mathrm{AX}$ as a checkpoint maintenance signal. Cell Cycle 5: 1376-1381, 2006.

22. Hayashi J, Kajino K, Umeda T, Takano S, Arakawa Y, Kudo M and Hino O: Somatic mutation and SNP in the promoter of dbpA and human hepatocarcinogenesis. Int J Oncol 21: 847-850, 2002.

23. Barzilai $\mathrm{A}$ and Yamamoto $\mathrm{K}$ : DNA damage responses to oxidative stress. DNA Repair 3: 1109-1115, 2004

24. Dianov Gl and Parsons JL: Co-ordination of DNA single strand break repair. DNA Repair 6: 454-460, 2007.

25. Chem JH, Ozanne SE and Hales CN: Heterogeneity in premature senescence by oxidative stress correlates with differential DNA damage during cell cycle. DNA Repair 28: 1140-1158, 2005.

26. Tanaka T, Halicka HD, Huang $X$, Tragonos $F$ and Darzynkiewicz Z: Constitutive histone $\mathrm{H}_{2} \mathrm{AX}$ phosphorylation and ATM activation, the reporter of DNA damage by endogenous oxidants. Cell Cycle 5: 1940-1945, 2006.

27. Tanaka T, Kajstura M, Halicka HD, Tragonos F and Darzynkiewicz Z: Constitutive histone $\mathrm{H}_{2} \mathrm{AX}$ phosphorylation and ATM activation are strongly amplified during mitogenic stimulation of lymphocytes. Cell Prolif 40: 1-13, 2007. 